\title{
SENSE-MAKING TECHNIQUES IN EDUCATIONAL PROCESS AND THEIR IMPACT ON THE PERSONAL CHARACTERISTICS OF STUDENTS
}

\author{
Dr. Irina V. Abakumova, Faculty of "Psychology, Pedagogy and Defectology”, Don State Technical University, \\ Rostov-on-Don, Russian Federation, \\ E-mail: abakira@mail.ru \\ Dr. Ekaterina S. Zorina, Southern Federal University, Rostov-on-Don, Russian Federation
} E-mail: kotenchik@yandex.ru

A R T I C L E I N F O

Original Research

Received: September, 12.2017.

Revised: October, 10.2017.

Accepted: November, 08.2017.

doi:10.5937/IJCRSEE1702041A

UDK

$159.922 .072-053.5$

615.851-053.5

\section{Keywords:}

psychotechnics,

sense-making techniques,

system of values,

meaning-making,

life-purpose orientation,

teaching,

upbringing.

\begin{abstract}
A B S T R A C T
This study looks into psychotechnics used in education and contributing to initiating logic among students, their personal growth and characterizes psychological features of "sense-deducting". Here you will find a review of the sense-making techniques considering as one of the categories of psychotechnics. The described techniques are based on the human psychology, they improve the quality of instruction, create a favorable and unique system of values, take into account the individual characteristics of all types of education, and influence the sense-making process development among children. Sense-making techniques are stated in the author's classification and extended by practical methods. The study of psychological features of influence of sense-making techniques on the personality of a student lets us see new patterns in personal, subjective and "meta-subjective" results of acquiring of the school program via transformation and development of value/logic consciousness of a child. The work emphasizes that the use of sense-making techniques is effective in the educational and after-school activities of the educational organization. The achieved results make it possible to understand, to substantiate the naturalness and relevance of the sense-technical approach according to personal and academic indicators of students. In the process of competent and correct use of the semantic techniques, we see the possibility of conveying the best, productive and quality pedagogical experience, as well as the perspective of innovative developments in the psychological and pedagogical sciences. For children and adolescents, information, thanks to sense-techniques, starts to be personal in nature, knowledge is objectified, learning activity becomes an individual need.
\end{abstract}

(C) 2017 IJCRSEE. All rights reserved.

\section{INTRODUCTION}

Modern challenges of global development suppose a constant enhancement of the education system as one of the crucial components of the human race evolution process. This fact finds its continuation in the search and testing of innovative forms and technolo-

Corresponding Author

Dr. Irina V. Abakumova, Faculty of "Psychology, Pedagogy and Defectology", DSTU, Rostov-on-Don, Russian Federation, E-mail: abakira@mail.ru

This work is licensed under a Creative Commons Attribution - NonCommercial - NoDerivs 4.0. The article is published with Open Access at www.ijcrsee.com gies of training that have to correspond to the achievements of psychological science and the demands of society. In practice, we are faced with the need for an integrated, multidisciplinary approach that allows not only the skills and knowledge transfer, but also the sense formation initiation as well as the reporting of value and cultural codes, and the facilitation of students' self-actualization.

In support of this over the past decades, many scientists have presented theoretical and empirical materials proving that the child's development can be studied and analyzed through the dynamics of the life-purpose orientation and value system development, since it is closely related to cognitive and emotional processes (Abakumova I. V., 2011; Abakumova I. V. et al, 2013; Anson W., 2004; Asmolov 
A. G., 1999; Asmolov A. G., 2009; Asmolov A. G., 2014).

The study of the possibilities and prospects of the sense-making paradigm in the humans' teaching and development is reflected in the works of Asmolov A. G. (sense-making pedagogy), Vasilyeva I. A., 2011. (the methods of working on author punctuation), Vorobyeva E. V. Ermakov P. N., 2015. (training of psychology students in the scientific methods of research), Fomenko V. T. et al, 2013. (the developing model of the content of education) and many other scientists. But in practical use, sense-making components, as applied to the educational process, are not enough. There is a request for the search and description of tools that allow students to provide meaningful activity, and the need for disclosure of sources that ensure a sense-making saturation of education. Technological aspects of the research (based on the textbook for masters of psychology and pedagogy (Abakumova I. V., 2011), typology of semantic problems in modern didactics (Zilberbrand N. Y. and Rudakova I. A., 2014.), psychological and didactic features of formation sense-making orientation (Nesterenko I. E., 2009), determinants of the sense-making activity of the individual on material of the study of senior students (Shreiber T. V., 2006), reflexivity features among children with different experience of solving "problems in the meaning" (Fayzullaeva E. D., 2013), psychological conditions for the formation of sense-making (Perelygina I. V., 2008), modularity of education and human integrity (Lankin V. G., 2012).

The system of value is a complex and multidimensional formation, consisting of a number of terms, but it sets the direction of cognition, the features of the key personality traits, motivational involvement of a person in life activity. Sense-making technique (in meaning-making point) is directly related to the individual life-purpose orientation, his existential experience and self-identification. The dominant idea of the sense-making technique in pedagogy and psychology is the creation of the immediate closeness to the child, considering his unique experience, the living space, the inner world. At the same time, the sensemaking techniques form the teaching skills, they can be disseminated, replicated, adapted for specific educational tasks, improve in the professional work of the teacher. Highlighting the sense-making techniques from the general variety of psychological techniques, we compiled a classification according to the possibilities of using the sense-making techniques in education (Table 1).

Table 1. Classification of sense-making techniques in educational sphere

\begin{tabular}{|c|c|c|c|}
\hline № & $\begin{array}{l}\text { Type of sense-making } \\
\text { techniques }\end{array}$ & Example & Practical Use \\
\hline 1 & $\begin{array}{l}\text { Sense-making } \\
\text { techniques, addressed to } \\
\text { subjective experience }\end{array}$ & $\begin{array}{l}\text { Personal association, } \\
\text { generalization, work with } \\
\text { images, personal-semantic } \\
\text { context }\end{array}$ & $\begin{array}{l}\text { The technique called "cluster", } \\
\text { "cinquain", "a basket for } \\
\text { ideas", the reproduction of } \\
\text { words - associations on a new } \\
\text { or previous topics, etc. }\end{array}$ \\
\hline 2 & $\begin{array}{l}\text { Sense-making } \\
\text { techniques of a dialogue }\end{array}$ & $\begin{array}{l}\text { External, internal, cultural, } \\
\text { epochal types of dialogue }\end{array}$ & $\begin{array}{l}\text { "Semantic questions", "Find } \\
\text { the riddle word", "Questions to } \\
\text { the Time Machine" }\end{array}$ \\
\hline 3 & Gaming techniques & $\begin{array}{l}\text { Role-playing, imitation, } \\
\text { game-travel, games with } \\
\text { natural materials, theatrical } \\
\text { plays, etc. }\end{array}$ & $\begin{array}{l}\text { Poetry quiz, role plays with } \\
\text { discussion, living through } \\
\text { situations }\end{array}$ \\
\hline 4 & $\begin{array}{l}\text { Sense-making } \\
\text { techniques of self- } \\
\text { expression }\end{array}$ & $\begin{array}{l}\text { Reflection, existential } \\
\text { choice, living through } \\
\text { situations, personalization }\end{array}$ & $\begin{array}{l}\text { Reflection of mood and } \\
\text { emotional state, reflection of } \\
\text { activity, reflection of the } \\
\text { content of educational material }\end{array}$ \\
\hline 5 & $\begin{array}{l}\text { Sense-making } \\
\text { techniques of support }\end{array}$ & $\begin{array}{l}\text { Emotional stroking, } \\
\text { situations of success and } \\
\text { recognition, life creation, } \\
\text { meaningful immersion, } \\
\text { value orientation }\end{array}$ & $\begin{array}{l}\text { The sense support techniques } \\
\text { find their embodiment in } \\
\text { gestures, intonation, teacher's } \\
\text { words, the practice of the } \\
\text { "Pollyanna effect", the defining } \\
\text { at the end of the lesson of the } \\
\text { achievements of students in the } \\
\text { nominations }\end{array}$ \\
\hline 6 & $\begin{array}{l}\text { Sense-making } \\
\text { techniques of creativity }\end{array}$ & $\begin{array}{l}\text { Art techniques, eurhythmy, } \\
\text { creative works, installations, } \\
\text { etc. }\end{array}$ & $\begin{array}{l}\text { Group pictures to the topic } \\
\text { under study, cartoons on the } \\
\text { issues under consideration, } \\
\text { drawing up diagrams, historical } \\
\text { collages, infographics, etc. }\end{array}$ \\
\hline 7 & $\begin{array}{l}\text { Sense-making } \\
\text { techniques of a } \\
\text { problematic character }\end{array}$ & $\begin{array}{l}\text { Tasks on "meaning", } \\
\text { "insight", Mindsight, } \\
\text { assignments on life } \\
\text { experiences, problematic }\end{array}$ & $\begin{array}{l}\text { "Blum's questionnaire } \\
\text { method", "Article for the } \\
\text { newspaper" technique, "Six } \\
\text { hats of thought" }\end{array}$ \\
\hline
\end{tabular}




\section{MATERIALS AND METHODS}

To implement the empirical part of the study, a practical base was formed; teachers and students from the following educational institutions of Rostov-on-Don participated: MAOU "School \# 39" in Leninsky district, MBOU "School \# 40" in Oktyabrsky district, MBOU "School \# 82" in Voroshilovsky district, "Palace of Creativity of Children and Youth" and the "Center for Children's Creativity" in Voroshilovsky district. They took a direct part in conducting a complex experiment to identify the psychological qualities of the influence of the sense-making and technical process on the educational process and schoolchildren's' system of value. Students of the second and third levels of education presented the respondents' composition of this study from 9 to 11 grades. Altogether there were 210 people, including 72 teachers.

The work initially examined the attitude of teachers towards psychotechnics in general and sense-making techniques in particular by questioning. After processing the results of the author's questionnaire, a working group was formed from the number of teachers interested in the sense-making approach or already using individual elements. It included teachers of history and social studies, Russian language and literature, psychological educators, teachers of additional education institutions, based on the conducted experiment, totaling 17 people. For teachers who were ready to work with sense-making techniques, a program to familiarize the sensemaking-based instructional method was developed. After a special training of the teachers who made up the group of innovators, from January 2014 to May 2016 of the academic year, the above-described semantic techniques were used in classes and after-class activities. In the course of the experiment, a complex model of the sense-making techniques using in the educational sphere was implemented, and a humanitarian-semantic examination was used to track the dynamics of the transformations in the value/semantic (or axiological) "consciousness" of the students. As a main criterion for choosing a semantic technician, we have singled out a description of the characteristics and dynamics of the system of value development among the students of grades 9-11, as well as carried out an analysis of the academic progress of children.

The study included two directions: humanitarian and psychological (students' value system/sense-making consciousness development in experimental classes) and academic (determining the degree of schooling in accordance with the generally accepted formula).

To study up the system of value, the psycho-pedagogical instrumentarium consists of psychometric, identification and introspective methods, as well as of methods that describe individual characteristics of adolescents.

Personal and life-purpose orientation diagnostics for students of the second and third levels of training was conducted in accordance with the characteristics studied [Table 2].

Table 2. Humanitarian and sense-making development study support

\begin{tabular}{|c|c|}
\hline $\begin{array}{l}\text { Sense-making } \\
\text { consciousness }\end{array}$ & $\begin{array}{c}\text { Diagnostic } \\
\text { technique }\end{array}$ \\
\hline $\begin{array}{l}\text { Sense-making } \\
\text { rationale }\end{array}$ & $\begin{array}{l}\text { Test of humorous phrases } \\
\text { by Shmelyov A.G. and } \\
\text { Babina V.S. }\end{array}$ \\
\hline $\begin{array}{l}\text { Attitude to the } \\
\text { surrounding reality, } \\
\text { a hierarchy of } \\
\text { values, meaningful } \\
\text { attitudes }\end{array}$ & $\begin{array}{l}\text { The "Human figure" test } \\
\text { by Harris G. } \\
\text { The "Personal biography" } \\
\text { test by Motkov O. }\end{array}$ \\
\hline $\begin{array}{l}\text { System of values } \\
\text { and life-purpose } \\
\text { orientation }\end{array}$ & $\begin{array}{l}\text { "Life-purpose } \\
\text { Orientations" test by } \\
\text { Rokich M. } \\
\text { "Unfinished sentences" } \\
\text { test }\end{array}$ \\
\hline $\begin{array}{l}\text { Personality } \\
\text { behavior regulated } \\
\text { by system of values } \\
\text { and life-purpose } \\
\text { orientation }\end{array}$ & $\begin{array}{l}\text { Approach by Abakumova } \\
\text { I.V. for determining the } \\
\text { level of personal and } \\
\text { sense-making } \\
\text { consciousness } \\
\text { development of } \\
\text { schoolchildren }\end{array}$ \\
\hline
\end{tabular}

The primary stage of the humanitariansensemaking study was implemented in the beginning of the 3rd term of 2014-2015 academic year. Two groups of adolescents were formed for the humanitarian-sensemaking examination. The first group was experimental and included three students of 9-11 grades in Voroshilovsky, Leninsky and Oktyabrsky districts, total 105 students. Lessons of history, social studies, law, the Russian language and literature, extra-curricular activities (quizzes, performances, debates, etc.) were carried out with based on the sense-making techniques. The second group was the control group with the same students of the 9-11 grades, a total of 105 students. They were engaged in traditional study programs without the use of the sense-making techniques.

After the training course based on the sense-making techniques for the schoolchildren experimental group were completed, the second stage of the study was implemented in 
April and May of 2016 year.

The choice of criteria for assessing the initiation of sense formation was focused on identifying the characteristics of changes in the sense-making consciousness development among the adolescent's personality, identifying leading motives, attitudes toward the surrounding reality, transformation of individual life-purpose orientation that were studied in the control and experimental groups at the beginning and at the end of the study. The choice of a diagnostic base with tests application and standardized methods was based on the idea of a single sense-making field for the formation and development of the value system and lifepurpose orientation.

\section{RESULTS}

We processed the results obtained from the control and experimental groups of schoolchildren data before and after the experiment. We used methods of statistical data processing, parametric (binomial distribution, quartile approach) and nonparametric statistics methods (determination of the Spearman rank correlation coefficient, Wilcoxon, Mann-Whitney, Friedman criterion) as well as an assessment of the data central trend and its spreading. As a result we determined that changes in the sense-making consciousness development among schoolchildren, which occurred in both groups during the period under the study, are more dynamic and pronounced among adolescents from the experimental classes where sense-making techniques were actively used in education and training. Schoolchildren from the experimental group demonstrated an aggression decrease with the predominance of orientation toward a peaceful way out of the conflict, and adequacy of evaluation of one's own person and surrounding people.

It is noteworthy that the sense-making development approach influenced the reorientation of values: the five most significant for the students included "Active Life", "Development", "Health", "Cognition", "Having good friends" points. Among the instrumental values were "Education", "Latitude of views", "Responsibility", "Tolerance", "Independence".

Positive appraisal dynamics were found on-scales "Attitude to the Future", "Life Goals", "Fears and anxiety", "Consciousness of Guilt", which indicates a constructive assessment and psychological maturity. The extremes have decreased too; extreme, cat- egorical assessments, especially negative ones transforms into neutral or less negative. Teachers conducted an independent expert review of the schoolchildren works determined that the sense-making techniques using positively influenced on the creativity development, individual creative abilities development, thinking imagery skill. The indicator of emotional well-being also grew, same as the motivation to communicate with other people increasing and rejection and aggression reduction.

The respondents of the experimental group demonstrated that the greatest changes occurred in such parameters as life self-determination, self-realization and personality transformation. Among them, we can state an increase in the number of adolescents with an average and high level of meaning-making development, which indicates self-actualization, the system of values improvement and lifepurpose orientation strengthening, self-analysis empowerment, objectivity development, same as the development of the ability to receive and comprehend information at different levels.

The analysis of academic indicators revealed a higher degree of schooling among schoolchildren who attended classes based on the sense-making approach, than did students from the control group who studied according to the traditional program.

\section{DISCUSSION}

Theoretical and empirical study of this topic allowed comprehensively approaching the phenomenon of the sense-making techniques. We can also study its influence on the educational process. The following conclusions were made:

1. There is a special kind of psychotechnics called sense-making techniques, which are directly connected with emotions, feelings and experiences of a person, his system of values, personal senses, life purpose orientation and meaning-making. These techniques form certain groups in the educational process and can be used depending on the subject area, the topic of the lesson, the goals to be achieved, and the socio-psychological characteristics of the students. This allows a teacher to form and improve the necessary sense-making instrumentarium.

2. Sense-making techniques introduc- 
tion in the educational process is possible only with the personal involvement of a teacher and after his/ her finishing the sense-making approach training course.

3. The methods and approaches included in the humanitarian-sensemaking studies correspond to the modern requirements for the evaluation and diagnosis of the personality characteristics of a person, same as his sense-making (meaning-making) consciousness, and are combined with classical methods of assessing the quality of education (calculating the schooling degree of classes in the subject).

4. The influence of the sense-making approach on the meaning-making consciousness development among the adolescents in the experimental group was reflected in the list of features:

- characterizing the changings in relation to themselves, the leading values for the students of the experimental group after the sense-making techniques introduction became education, responsibility, independence; self-conception is harmonized as the number of positive and neutral assessments in the analysis of the indicators «consciousness of guilt» and "attitude toward oneself» were increased; there was also an increase in the overall constructiveness of the individual among schoolchildren; the criterion of the quality of life self-realization and the capacity for transformation has increased, indicating an intensification of the processes of meaning-making and its interpersonalization;

- as for interaction, the tendency towards a decrease in the level of aggression was noted, as the predominance orientated toward a peaceful way out of the conflict presented; a balanced assessment of the actions and behavior of others, tolerance for the shortcomings of others were also noted. A relationship with the father, family, school and teachers, which constitutes the basic circle of communication and interaction at school age, became better; the value of «having good friends», «tolerance», «breadth of views», «happiness of others», «sensitivity» increased in the reference communication.

- a transformation of social meanings took place: the transformation from situational to stable personalities conditions was evidenced by the revealed correlation dependence: with the growth of the motive «human stupidity», the values «having good friends», «public recognition», «independence», «honesty», «productivity», «intransigence to shortcomings», «cognition» were grew up; but at the same time, a significant reduction in the expression of the value «happiness of others»" and «breadth of views»; with the growth of the motive «mediocrity in art», the importance of values such as "productive life», «tolerance», «sensitivity», «courage in upholding one's opinion» naturally grows, but «efficiency in business» is reduced. The number of adolescents with an average and high level of sense-making consciousness development has increased, which indicates self-actualization development too, same as the improvement of the system of values and lifepurpose orientation strengthen, the opportunity for self-analysis and objectivity skills appearing and the development of the ability to receive and comprehend information at different levels.

5. The introduction and use of sensemaking techniques approach in the educational process is possible only with the comprehensive development of the instructional method programs for the use of the sensemaking techniques in a certain subject area, taking into account the specifics of the educational institution, the work program and the requirements of the Federal State Educational Standard. 


\section{CONCLUSION}

A comprehensive analysis of the results of psychological methods included in the humanitarian-sensemaking study made it possible to determine that the introduction of sense-making techniques approach into educational and upbringing program is such a way of organizing the educational process which will ensure the development of sense-making consciousness development, as well as the initiation of meaning formation and the transformation of knowledge into Personal level.

\section{ACKNOWLEDGMENTS}

The article is executed within the project "Development of technologies of initiation of a sense-making as component of modern communicative systems for the purpose of ensuring information security of the Internet” № IntGr-07/2017-01.

\section{Conflict of interests}

The authors declare no conflict of interest.

\section{REFERENCES}

Abakumova I. V. (2011). Smyslodidaktika. Uchebnik dlja magistrov psihologii i pedagogiki. [A textbook for masters of psychology and pedagogy]. Second edition. T. M.: CREDO Publishers, 449.

Abakumova I. V, Ermakov P. N., Fomenko V. T. (2013). Novodidaktika. Kniga 1. Metodologiya i tekhnologii obucheniya: v poiskakh razvivayuschego resursa. [New Didactics. Book 1. Methodology and teaching Technologies: in search of developing resource.] T. M.: CREDO Publishers, 162.

Anson W. (2004). Effects of teaching self-monitoring in a distance learning course. Doctoral thesis University of Southern California, USA. https:// www.learntechlib.org/p/115517/

Asmolov A. G. (1999). Psihologija XXI veka i rozhdenie variativnogo obrazova-tel'nogo prostranstva Rossii. [Psychology of XXI century and advent of variable educational environment]. Mir psihologii [The World of Psychology], 1, 198208. http://nrpsy.ru/teoria_problemi_asmolov. html

Asmolov A. G. (2009). From we-media to I-media: Identity transformations in the virtual world. Psychology in Russia: State of the art, 2(1). http://psychologyinrussia.com/volumes/ pdf/2009/05 2009 asmolovi.pdf

Asmolov A. G. (2014). Dopolnitel'noe personal'noe obrazovanie $\mathrm{v}$ epohu peremen: sotrudnichestvo, sotvorchestvo, samotvorenie. [Supplementary personal education in the time of change: co-operation, co-creativity, self-making]. Obrazovatel'naja politika [Educational policy], 2(64), 2-6. http://edupolicy.ru/wp-content/uploads/2014/07/Asmolov-№2.2014.pdf
Fayzullaeva E. D. (2013). Izucheniye osobennostey refleksivnosti u detey s raznym opytom resheniya «zadach na smysl». [The study of the reflexivity features among children with different experience of solving "problems in the meaning"]. "Vestnik" [Collection of news] of the Krasnoyarsk State Pedagogical University, 1(23), 151-155. http://sun.tsu.ru/mminfo/2010/000394912/000394912.pdf

Fomenko V. T., Abakumova I. V., Telnova O. V. (2013). The Developing Model of the Content of Education in General Education. Russian Psychological Journal, 10(4), 7-14. Retrieved from http:// rpj.ru.com/index.php/rpj/article/view/66/97

Lankin V. G. (2012). Modul'nost' obrazovaniya i tselostnost' cheloveka: k kriteriyam ekspertizy gumanitarnykh praktik. [Modularity of education and human integrity: to the criteria for the expertise of humanitarian practices]. Vestnik nauk Sibiri. Seriya 8. Obshchestvennyye nauki. [Siberian collection of news of social sciences], 1(2), 203-209. http://earchive.tpu.ru/bitstream/11683/15996/1/209.pdf

Nesterenko I. E. (2009). Psikhologo-didakticheskiye osobennosti formirovaniya smyslovykh ustanovok starsheklassnikov $v$ uchebnom protsesse. [Psychological and didactic features of formation sense-making orientation among high school students in the educational process]. $\mathrm{PhD}$ in psychological studies, 24. http://nauka-pedagogika.com/viewer/309004/d\#?page=1

Perelygina I. V. (2008). Psikhologicheskiye usloviya stanovleniya tsennostno-smyslovykh ustanovok studentov $v$ protsesse samoproyektirovaniya zhiznennoy pozitsii. [Psychological conditions for the formation of sense-making tic installations of students in the process of self-projecting life orientation]. Psychol. sciences, 235. http://nauka-pedagogika.com/viewer/269100/ $\mathrm{d} \#$ ? page $=1$

Shreiber T. V. (2006). Determinanty smysloobrazuyushchey aktivnosti lichnosti: Na materiale issledovaniya starshikh shkol'nikov. [Determinants of the sense-making activity of the individual on material of the study of senior students]. $\mathrm{PhD}$ in pedagogy, 22. http://nauka-pedagogika.com/ viewer $/ 160501 / \mathrm{d} \#$ ?page $=1$

Vasilyeva I. A. (2011). Metodika raboty nad yavleniyem avtorskoy punktuatsii $v$ starshikh klassakh. [The methods of working on author punctuation in high school]. PhD in pedagogy studies, 246. http://nauka-pedagogika.com/viewer/361889/ $\mathrm{d} \#$ ? page $=1$

Vorobyeva E. V., Ermakov P. N. (2015). Training of psychology students in the scientific methods of research. Procedia - Social and Behavioral Sciences. The Proceedings of 6th World Conference on educational Sciences, 2699-2703. https://doi.org/10.1016/j.sbspro.2015.04.396

Zilberbrand N. Y., Rudakova I. A. (2014). Tipologiya smyslovykh zadachv sovremennoy didaktike. [Typology of semantic problems in modern didactics]. Modern problems of science and education № 5 (part 1), 177-181. https://fundamental-research.ru/ru/article/view?id=33809 